\title{
Conceptual Metaphor as a Means of Terrorist Suggestion (on the Material of the Islamic State Video Messages)
}

\author{
Andrey Fomin and Elizaveta Mona \\ Kemerovo State University \\ 650000, 6, Krasnaya St., Kemerovo, Russia
}

\begin{abstract}
Manipulative verbal influence is an immanent feature of modern international communication. Successful realization of the suggestive aspect allows the speaker to exert influence on the recipient's worldview and ingrain certain ideological attitudes in their mind. This situation is characteristic of various types of discourse: political, advertising and media. However, the most dangerous for political stability and safety is utilization of persuasive linguistic devices by extremist groups and terrorist organizations. Thus, research in this field has become extremely relevant. The article presents linguistic analysis of such manifestations of destructive manipulation in the Islamic State (IS) speech, found in their official video messages. The analysis was carried out on the material of the official IS video messages, obtained through the selective sampling method on the video hosting website YouTube. Within the framework of the research we distinguish, classify and subject to a thorough linguistic analysis of conceptual metaphors which are used by the terrorists. The data obtained enables us to make a conclusion regarding the key role of conceptual metaphor in realization of the IS speaker's communicative intention, which presupposes attracting the recipient's attention to their activities and creating a radicalized ideological attitude in the minds of the audience. Furthermore, we prove that the metaphor is deliberately used by the terrorists to successfully fulfill their pragmatic intention, which involves manipulating the recipient. The provisions developed as part of the study and the results of the analysis can be further applied in modelling the mechanisms to confront and counteract terrorist suggestion in cyberspace and mass media.
\end{abstract}

Keywords: communicative intention, conceptual metaphor, terrorist discourse, suggestive influence, linguistic manipulation, verbal extremism

\section{For citation:}

Fomin, Andrey and Mona, Elizaveta (2019). Conceptual Metaphor as a Means of Terrorist Suggestion (on the Material of the Islamic State Video Messages). Russian Journal of Linguistics, 23 (3), 698-713. doi: 10.22363/2312-9182-2019-23-3-698-713. 


\title{
Концептуальная метафора как инструмент реализации террористической суггестии (исследование на материале видеообращений исламского государства)
}

\author{
А.Г. Фомин, Е.А. Мона \\ Кемеровский государственный университет \\ Красная, 6, Кемерово, 650000, Россия
}

\begin{abstract}
Аннотация
Манипулятивное речевое воздействие является имманентной чертой современной международной коммуникации. Успешная реализация суггестивной задачи позволяет спикеру влиять на мировоззрение реципиента и внедрять в его сознание определенные идеологические установки. Подобная ситуация характерна для различных дискурсов: политического, рекламного, медийного. Однако наиболее опасным для политической стабильности и безопасности целевой аудитории является применение речевых приемов и языковых средств реализации персуазивной стратегии экстремистскими группировками и террористическими организациями. В связи с этим, исследования в данной области являются на сегодняшний день крайне актуальными. Данная статья посвящена лингвистическому анализу подобных проявлений деструктивной манипуляции в устной речи спикеров Исламского Государства (ИГ), зафиксированной в официальных видеообращениях. Материалом для работы послужили официальные видеозаписи террористов ИГ, отобранные методом направленной выборки на видео хостинге YouTube. В рамках исследования выделяются, классифицируются и подвергаются детальному лингвистическому анализу концептуальные метафоры, употребляемые террористами. Результаты анализа позволяют выявить ключевую роль концептуальной метафоры в достижении спикером ИГ коммуникативной цели, заключающейся в привлечении внимания к своей деятельности и создании радикальной идеологической установки в сознании общественности. Также доказывается, что метафора целенаправленно используется террористами и для успешной реализации прагматической установки, предполагающей оказание манипулятивного воздействия на реципиента. Положения, разработанные в ходе исследования, и полученные результаты анализа могут быть в дальнейшем применены при моделировании механизмов противостояния и противодействия террористической суггестии в киберпространстве и медийной среде.
\end{abstract}

Ключевые слова: коммуникативная интенция, конщептуальная метафора, террористический дискурс, суггестивное воздействие, языковое манипулирование, вербальный экстремизм

\section{Для цитирования:}

Fomin, Andrey and Mona, Elizaveta (2019). Conceptual Metaphor as a Means of Terrorist Suggestion (on the Material of the Islamic State Video Messages). Russian Journal of Linguistics, 23 (3), 698713. doi: 10.22363/2312-9182-2019-23-3-698-713.

\section{Introduction}

To date, extremist groups' and terrorist organizations' use of information and communication technologies is considered to be one of the most socially significant global problems. More specifically, in order to propagate their destructive ideology, the Islamic State (henceforth - the IS) militants employ various communication tools, which enables them to achieve a great public impact by manipulating mass media. The terrorists issue leaflets containing threatening slogans and make use of audio and video equipment to record their messages, which are further uploaded onto various websites 
accessible to the general public. Such activities are examples representative of "verbal extremism". As a rule, since verbal extremism is used to achieve political goals, the influence of advanced means of propaganda on mass audience in causing public uproar is quite significant (Korosteleva 2015: 20).

Nowadays manipulative influence is commonly revealed in public speech. Radical groups try to reach massive target audience by subliminally applying linguistic means of social mind manipulation. Manipulation might be considered as a form of persuasion. However, whereas persuasion provides the recipient with a choice of whether to accept certain ideas and perform some actions or not, manipulation makes the recipient more passive, unable to resist the speaker's suggestion (Van Dijk 2006). Linguistic manipulation, which is defined in the following way: hidden verbal influence on a recipient intentionally making them confused concerning the initial meaning and contents of speech (Danilova 2009: 12), is regarded as an immanent feature of modern international communication. Moreover, it is a complex means of unilateral communicative influence of psychological nature successful use of which by the addresser creates subtle motivation, provoking incipience of beliefs and desires that are not peculiar to the addressee and creating an illusion of self-made decisions; linguistic manipulation makes a person behave in terms of certain stereotypical ideas and a different view of reality, imposed by the misfeasor (Bubnova 2012: 87). As stated elsewhere, in most cases the influence on a recipient is not evident and is accomplished through specific phrasing. Furthermore, it rarely correlates with lying or distortion of facts (Chernyavskaya 2006: 15).

Successful actualization of linguistic manipulation depends on the speaker's range of linguistic means, the most significant being the lexemes that contain an emotive component. Taking into consideration the fact that the main aim of subtle linguistic manipulation is forming definite attitude towards some public or political events in minds of target recipients, a speaker needs to pay special attention to putting new meanings and connotations into lexical formatives to be used, as well as to choosing a synonymous word containing either pejorative or meliorative emotive component (depending on the speaker's intention). While modelling a text an author of manipulative messages tends to choose mostly neutral lexis from any semantic field, though such words are able to obtain the traits necessary to exert influence, since being opposed to words with strong negative connotation they subtly present positive attitude towards a particular object, reflecting the position of the whole ideology system (Larina et al. 2011: 28 - 29).

Thus, it can be stated that in order to make an utterance an efficient recruitment tool an author of a manipulative message has to be extremely mindful of verbal organization of the text which is supposed to affect the recipients' consciousness. Suggestive influence is implemented not only by using certain communicative strategies and tactics but also by applying a vast number of linguistic expressive means. According to linguists, conceptual metaphor is one of the most productive linguistic means of manipulative influence as it was noted that the sources of metaphoric expansion are public realia (Gornostaeva 2018: 113). As a result of such influence an individual becomes immersed into the sphere of information phantoms which can be fraught with destructiveness, misinformation and anti-social mindset (Zaripov 2014: 147). Thus, metaphor use should be regarded as "a complex process of metaphor production-cum-reception, which goes 
fundamentally beyond the mere "application" or "processing" of mappings" (Musolff 2019: 35-36). R. Entman, a professor of communication and political science, stated that there are certain weak points in human consciousness connected with ignorance and prejudice. Detecting and making use of them to propagate means controlling people's minds (Budaev 2007: 71).

From the perspective of language studies verbal means that make manipulation possible are identified as instruments of linguistic violence - unreasoned or poorly reasoned verbal influence, the aim of which is to deform an individual's personal attitude (mental, ideological, axiological etc.). It is worth noting that manipulation is becoming more aggressive, the main aim of linguistic manipulation accentuated by verbal and nonverbal aggression is to deliberately mislead the audience imposing on it the desired idea of ideological subordination (Ozyumenko 2017: 220; Ozyumenko, Larina 2017). Linguistic violence presupposes the presence of ideological mythologems, euphemisms and dysphemisms, irony and offensive utterances aimed at "demonization" (which, according to S. Ivanova (2016), is one of the main techniques of deliberate creation of a negative, more preferably a repulsive, image of the opponent) in a person's speech (Kopnina 2008). Using such means is always accompanied by an essential number of linguistic devices. Metaphor is regarded as the most prominent one since it has both euphemistic (creating a positive image) and dysphemistic (creating a negative image) potential. Moreover, constant repetition of the same metaphoric models within a text of any discourse provides systematical continuous pressure on the target audience (Zaripov 2014: 149). G. Baigarina (2004) also notes that active use of a metaphor with its ability to change perception in a way it is desired should be seen as refusing to openly propagate ideas and shows a speaker's intention to manipulate the general public subtly.

\section{The Conceptual Metaphor Theory: Definition and Functions}

The correlation between language and cognition became most relevant in linguistics during the 1980s - 90s. The research devoted to this issue helped to provide the extensive theoretical basis, the principles of which served as a foundation for a new scientific discipline - cognitive linguistics. Studying conceptualization and verbalization specificity of psychological processes in this scientific field enables the researchers not only to consider the data concerning a referent of nomination but also to describe mental constructs of consciousness (responsible for storing, processing and passing on knowledge) within the analysis (Kuprieva 2013: 45).

One of the most important achievements of cognitive linguistics is the conceptual metaphor theory, the basics of which were first outlined in G. Lakoff and M. Johnson's work "Metaphors We Live By". Lakoff and Johnson were the first to treat the phenomenon of transfer of meaning as a metaphoric occurrence or a conceptual metaphor. The term "conceptual metaphor" was defined by the authors as a cognitive process that underlies differentiation of linguistic means of an expression (Lakoff, Johnson 2008). This approach takes into account various features of human learning as a linguistic personality, whose mental activity determines the peculiarities of individual language use. Thus, metaphor becomes a complex notion that exceeds the boundaries of the 
language system and, therefore, can be regarded as a phenomenon stemming from the interplay between language, cognition and culture.

In publications to follow, the researchers defined "the source domain" and "the target domain" (in several works by Russian linguists it is possible to see the terms translated as "the donor zone" and "the recipient zone"). G. Lakoff's invariance hypothesis plays the key role in understanding the correlation between these notions. Lakoff and Johnson hypothesize that source domain preserves "cognitive topology" of the target domain, i.e. it inherits the structural framework from the target domain as a set of basic elements and how they correlate (Skrebtsova 2018: 45).

Lakoff and Johnson state that the primary function of conceptual metaphor is that it allows us to simplify and concretize extremely complex situations, phenomena and notions (ideas, emotions); metaphor is considered to be the only way to comprehend the abstract (Lakoff, Johnson 2008). Thus, it could be presumed that in terms of analyzing the limited linguistic valence of an abstract notion, it becomes possible to restore an individual's mental images, connected with the primarily described object. This, in turn, proves the significance of modelling metaphorical expressions as a means of examining an individual's conceptual framework.

Regular use of concrete images in relation to any phenomenon permits a conclusion about the presence of corresponding conceptual metaphor in a linguistic personality's mind. It is noteworthy that conceptual metaphors are often used by native speakers unconsciously (unintentionally) due to certain concepts being rooted in their cognition. A compelling example of this situation is the existence of the so-called "trite" or "dead" metaphors. While analyzing the language material, Lakoff and Johnson opt for working with this type of metaphor, since, according to their theory, it is the average metaphors that allow the researchers to identify conventional means of comprehending reality by an individual. In "genuine" or "original" metaphors, which are perceived as occasional, the resulting image is noticeable to the speaker (Skrebtsova 2018: 46).

Nevertheless, this article is primarily focused on "genuine" conceptual metaphors, since they have been used deliberately within the context of terrorist narrative, which allows us to examine their role in fulfilling the communicative intention of the speaker to have a destructive effect on a recipient's mind. Furthermore, we have previously proved the hypothesis that IS terrorist speech is a preconceived text, the author of which cannot be solely the speaker himself (Fomin, Mona 2016). Therefore, the conclusion that occasional metaphors are more intrinsic to an individual's cognition is inapplicable in terms of this research. We can also justifiably make additions to opinions regarding cultural foundation of conceptual metaphors - we believe that their use might also be contingent on the speaker's social background (in this case, being part of a terrorist organization).

\section{Classification of Conceptual Metaphors}

Based on the nature and means of conceptualization of objects and events, G. Lakoff and M. Johnson identified three types of conceptual metaphors: orientational, structural and ontological. 
Orientational metaphors are the most prevalent ones. This type of metaphorical conception is defined as follows: "there is another kind of metaphorical concept, one that does not structure one concept in terms of another but instead organizes a whole system of concepts with respect to one another. We will call these orientational metaphors, since most of them have to do with spatial orientation" (Lakoff, Johnson 2008: 14). As they are grounded in our physical and cultural experience, such metaphorical orientations are not arbitrary. It is consistency of orientational metaphors that makes them appear systematic. With the help of orientational metaphors in many cultures it becomes possible to describe physical, emotional and social condition of an individual; moreover, spatial characteristics of ideas and events may be equated with their assessment. These are metaphors based on spatial oppositions (e.g., "up — down", "left — right", “central - peripheral") (Kondrat'eva 2002). However, Lakoff states that "though the polar oppositions up-down, in-out, etc., are physical in nature, the orientational metaphors based on them can vary from culture to culture. For example, in some cultures the future is in front of us, whereas in others it is in back" (Lakoff, Johnson 2008: 35). Frequency of orientational metaphors used in a specific linguistic community highlights the peculiarities of worldview in cognitive classifications. Human interaction with the environment naturally results in rationale for constructing spatial metaphors; those that are more frequently used and fixed in an individual's mind vary from culture to culture.

Although orientational metaphors, ingrained in the minds of bearers of a particular culture, are closely connected with the culture's fundamental values, various subcultures can interpret certain concepts differently. Regardless, the systems of group and individual values primarily correspond with basic orientational metaphors of the said culture. This proposition is invaluable for the current research, as terrorists, being bearers of a radical subculture (and, consequently, bearers of a particular ideological worldview), have a distinct perception of good and evil from the majority. However, despite their distorted perception of reality, the IS terrorists appeal to basic values of Muslim culture in each and every video message.

Using the category of spatial orientation to comprehend the surrounding reality is so trivial in daily life that it occurs, as a rule, unconsciously. Equally natural a process is interpretation of personal experience in terms of physical objects and substances an individual unknowingly divides it (similarly to a discrete object) into specific parts, which are then grouped, evaluated, etc. Lakoff and Johnson define such operations using the so-called ontological metaphors (Lakoff, Johnson 2008).

Ontological metaphors are quite diverse. The most prevalent ones are, for instance, "metaphors of entity", which enable one to comprehend the abstract through the concrete. Interpretation of abstract concepts via terms used for describing physical objects allows referring them, quantifying, seeing the reason for something in it, making decisions regarding further actions, etc. (Chyudinov, Budaev 2007). The initial notion, as a result, takes the form of a tangible, material entity; the abstract thought leaves the boundaries of imageability that hinders perception.

Another type of ontological metaphors is also the personification metaphor, which is used to comprehend inanimate objects and abstract notions in terms of qualities and 
characteristics intrinsic to a human being. Personification is a general category, which includes a subset of more specific metaphors that use separate human qualities to transfer meaning.

Orientational and ontological metaphors, based on physical notions, underlie the human conceptual system. However, their use does not yield enough information regarding the "target domain". Using more concrete concepts to comprehend a notion and conceptualize its essence in greater detail is possible only in case of structural metaphors.

A prominent feature of the structural metaphor is that they ensure only partial structuration of the target domain with the help of the source domain. This proposition can be exemplified by a quick analysis of the structural metaphor "time is money". In reality, these objects are not equal, and, therefore, the qualities and the properties of one object do not correspond with those of the other. For instance, unlike money, time wasted cannot be reimbursed. Subsequently, it is possible to conclude that any metaphor is simultaneously highlighting and obscuring or obfuscating various characteristics of a notion (while one aspect is emphasized, the other is de-emphasized) (Skrebtsova 2018: 52-53).

The most complex case of obscuring certain aspects of a notion is the conduit metaphor, which was first described by M. Reddy. This metaphor is used to structure human perception of the nature of language and communication. Here, the object of metaphorization is ideas or meaning, with the containers being linguistic expressions, and the conveyor being communication itself. The speaker puts certain ideas (objects) into words (= containers) and sends them (along a conduit) to a hearer who takes the idea / objects out of the word / containers and deciphers the message (Reddy 1979). The examples of the conduit metaphor are such expressions as "your words are empty" or "the sentence is without meaning". Similar expressions are fairly trivial, as the metaphor that underlies them is rarely recognized. It is seemingly natural to assume that linguistic expressions (words and sentences) contain meaning that can be discerned and scrutinized. However, A. Vezhbitskaya points out that the very idea that "a word / sentence has a meaning" is metaphorical and, as a result, is substantially different from a literal statement (e.g. "He has a well-paid job"). As the metaphor at the core of these expressions is not recognized, it is obvious that they obscure some aspects of the communication process. This idea found a response in Lakoff and Johnson's works as well. The statement "a word / sentence has a meaning" presupposes that meanings exist independently from people that use them, which contradicts basic principles of cognitive linguistics (Vezhbitskaya 1996: 147).

The authors of "Metaphors We Live By" pay particular attention to the danger of literal interpretation of metaphorical expressions. In order to understand this problem fully, it is necessary to examine the theory of the so-called computer metaphor. Although the majority of researchers agree that it is counter-productive to describe human brain activity using computer terminology, expressions such as "a human is processing information" are still found in scholarly works and everyday speech. Cognitive processes are universally described through operations, algorithms, formats, created to represent knowledge in computers (networks, frames, models, etc.). These analogies create 
an illusion that humans think according to the laws of formal logic. The emphasis shifts from meaning to information (thus, the abovementioned obfuscation takes place), and the computer metaphor is recognized less and less; gradually, the "mechanistic representations of cognition" become more dominant (Skrebtsova 2011: 45-46).

The illustrated ontologization of the computer metaphor allows us to reveal another substantial feature of metaphors, which was first examined thoroughly by Lakoff and Johnson. It is the "metaphorical creativity". It means that an individual, while using a metaphor, not only interprets the surrounding reality but also creates a new one. This feature of the metaphor allows the bearer of a specific ideology to exploit this device to create the desired image in the recipient's mind: as a result, conceptual metaphor becomes a powerful means of suggestive influence (Skrebtsova, 2018: 57).

\section{Conceptual Metaphor in Political Discourse}

Conceptual metaphors are used by politicians and the military in a drastically different way when describing an armed conflict, the main function becomes not conceptualization of notions but manipulation of public consciousness. As pointed out by George Lakoff, who was the first to apply the conceptual metaphor theory to language material in political discourse, in 1990-1991 official speeches of the US politicians indoctrination and recruitment of the public was the primary focus of the country's administration, pursuing their own "selfish goals" and having economic interest in the outbreak of the war (Lakoff 2003). As noted previously, any metaphor highlights certain characteristics of a notion by obfuscating or obscuring the others. In this case, American politicians made regular use of conceptual metaphors in their speeches and statements, which helped them to conceal negative outcomes of military actions (death, loss of loved ones, injuries, trauma, etc.) that the US citizens would face if there were war. Lakoff characterized this use of metaphors as immoral and deemed it necessary to thoroughly analyze the US government's argumentation within the framework of the conceptual metaphor theory. He identified main conceptual metaphors in speeches, revealed the aspects they were supposed to obscure and made the case for insolvency of the official argumentation from the ethical, military, political, and economic standpoints (Skrebtsova 2018: 66).

G. Lakoff's article became a fundamental work that laid the ground for the analysis of political language in terms of the conceptual metaphor theory. The important role of metaphor in political discourse was demonstrated thoroughly and convincingly. By being able to create required images in the recipient's mind and conceal undesirable aspects of the notion that the speaker is relaying, conceptual metaphors serve as a tool for politicians to control public opinions and influence many political processes (Skrebtsova 2011: 59).

\section{Conceptual Metaphor in Terrorist Discourse}

The existence of pro-Islamic radical groups and provocative behavior of their representatives provoke negative public opinion. Muslim revelators criticize actions of such communities, which, according to their beliefs, have nothing in common with real postulates of Islam and spread aggressive inhumane artificial ideology. Therefore, prevarication takes place in polylingual environment. The discourse created by the Islamic 
State is an example of "destructive communication", which is extremely dangerous for public consciousness and leads to drastic changes in a person's value perception of the world, as a speaker aggressively inserts a subject matter into the addressee's perceptive field and makes him perform some action beneficial for the misfeasors (Komalova 2013: 151).

In this article we understand the term "destructive" as consciously performing aggressive actions in order to make someone suffer without feeling any remorse and, on the contrary, being satisfied because of such actions. Destructive communication, therefore, is a type of communicative interaction, aimed at causing an interlocutor mental or physical damage and accompanied with epicaricacy (Volkova, Panchenko 2016: 168). In the framework of the conceptual metaphor theory destructive communication is defined quite generally as forms and specific features of contacts which negatively affect the interlocutor and complicate interaction (Kunitsina et al. 2001: 271). Linguistic manipulation is a shining example of this phenomenon, since it restructures individual consciousness by inculcating new categories in case of the successful implementation of persuasive (influence on the addressee through oral or written speech aimed at exhortation and making an individual do or avoid doing a certain action) (Chernyavskaya 2006: 26) or suggestive (subtle, mostly verbal influence which results in changing someone's intentions, objectives and ideas in the atmosphere of free choice) strategies (Nickl 1998: 27).

There is no doubt that linguistic means of emotional expressiveness (especially conceptual metaphor) play an important role in stylistic organization of publicly presented texts of manipulative essence - the use of them helps to ensure that the final product will not be commonplace or easily forgotten and enables authors of radical messages to create vivid images in recipients' memory (Ermoshin 2011: 5-6).

Since analysis of conceptual metaphors enables researchers to reveal implicit meanings in a speaker's utterance, define communicative intention of an author of a message and demonstrate his social position, this method is considered applicable for any discourse. This research is carried out within the terrorist discourse, which is defined as a complex of oral and / or written texts created by terrorists and extralinguistic features explaining their specificity (for instance, common pragmatic intention and motivation of the IS speakers or the fact that they belong to the social group "terrorists". It should also be stated that structurally we see the terrorist discourse as a subtype of the extremist discourse which is itself part of the political discourse (in other words, terrorist discourse is one of the constituents of political discourse).

Within the framework of the terrorist discourse we shall examine in detail terrorists' video messages from the standpoint of the conceptual metaphor theory. The choice of video messages (which are to some extent examples of public speech) as the object of this research is justified by the fact that nowadays such models of conveying information to huge amounts of recipients is rather common. The main aim of this form of communication is finding the most effective ways and means of suggestive influence to propagate some ideology (Ivanova 2013: 37). Another objective of radical video messages presented to the general public is to eliminate any cause of hesitation which can make a recipient start questioning the validity of the speakers' arguments. Set expressions might lose power of conviction if the addressee of a message starts noticing them 
due to frequent use. That is why authors of such tests must be ingenious to hold the attention of the subject of linguistic manipulation. Making use of linguistic means (lexical and syntactic) serves this goal. Lexical means include linguistic devices, the main one of which is metaphor (Savosin 2013: 78-79). This determines the necessity of analyzing conceptual metaphors in the IS video messages.

\section{Analysis of Conceptual Metaphor in Islamic State Video Messages}

Within the framework of the research the selective sampling method was applied to create the data corpus for further analysis. Thus, seven official IS video messages originally made in English were taken from YouTube (the most visited video hosting website available to the general public). According to various news outlets, Englishspeaking IS members come from the UK (Mohammed Emwazi, also known as "Jihadi John", and another currently unidentified terrorist), Australia (Abdullah Elmir, also known as "Ginger Jihadist") and Canada (John McGuire). The selected video messages were then transcribed by us, which made it possible to identify the most prevalent conceptual metaphors in the texts.

An orientational conceptual metaphor discovered in the terrorists' texts is the idea WE-ON-TOP - ENEMY-UNDER-OUR-FEET. This image is created with the help of the following expressions:

(1) "put the black flag on top of...", used by the terrorist to convey the meaning "claim victory over the enemy" ("Until we put the black flag on top of Buckingham Palace, until we put the black flag on top of the White House");

(2) "to be under one's feet"; the meaning of this metaphorical expression consists in being in a state of helplessness and inability to protect one's life ("...know that today your citizenship is under our feet").

These examples illustrate the opposition "up — down", where the author's preferred processes and events are primarily connected with the concept UP, and the least desirable one - with the concept DOWN. This way, the IS terrorists reinforce their idea of superiority over the enemy, presenting the latter as feeble and unable to retaliate.

With a view to ontological metaphors, we deem it necessary to distinguish the ENEMY-ANIMAL model, where the former concept is the target domain, and the latter is the source domain.

\section{ENEMY $\leftarrow$ ANIMAL \\ target domain source domain \\ Mechanism of an ontological conceptual metaphor (exemplified in ENEMY-ANIMAL)}

Since the target domain preserves "cognitive topology" of the source domain, we can observe transfer of the structural framework of the latter into the metaphorical field of the former:

\begin{tabular}{|c|c|}
\hline ENEMY & ANIMAL \\
\hline (3) kill, murder & slaughter \\
\hline (4) David Cameron & swine, lapdog, mule \\
\hline (5) Barack Obama & dog \\
\hline
\end{tabular}


Consider the following examples:

(3a) "The blood of David Haines was on your hands David Cameron. Alan Henning will also be slaughtered but his blood is on the hands of the British parliament".

(3b) “...this knife will not only slaughter Kenji...”

According to Oxford English Dictionary, the first meaning of the verb "to slaughter" is "the killing of animals for their meat" (OED Online). Thus, the speakers dehumanize their victim by equating the latter to an animal, which helps to intimidate the recipients of the message. It is noteworthy that the speaker then shifts the blame onto "the British Parliament", reinforcing the idea that such actions are justified and are performed in retaliation to aggression from Western countries. The purpose of this metaphor is, firstly, to create panic in minds of the recipients by presenting the terrorist organization as a ruthless force that will show no remorse towards their enemies, and, secondly, to draw the attention of the target audience to the act of killing and immediately making the viewer feel complicit in the death of the victim.

(4a) "Your evil alliance with America, which continues to strike the Muslims of Iraq and most recently bombed the Haditha Dam, will only accelerate your destruction and claim the role of the obedient lapdog".

Oxford English Dictionary defines a lapdog as "[a] small pampered pet dog". However, the second meaning is "[a] person or organization which is influenced or controlled by another" (OED Online). Such nomination can be considered a conventional metaphor, i.e. which is commonly used in everyday speech to the point that it could have lost its imagery. While the metaphoric meaning behind "lapdog" has been recorded in dictionaries, it could be argued that imagery here is still quite vivid and evocative. So, we deem it reasonable to attribute this instance to the ENEMY-ANIMAL model. This metaphor is used by the terrorist to diminish and insult David Cameron, then incumbent Prime Minister of the UK, by presenting his actions as blindly following the orders of the US government. One could argue that the terrorists' agenda in this case is to make their British viewers feel doubtful about the British policies regarding their stance on the issue and shift the recipients' attention from the murder of the victim to their government's role as a "puppet" of the US (cf.: "... like your puppet David Cameron said..." in a video message addressed to Barak Obama).

(4b) "This is a message to that despicable swine David Cameron".

The Oxford dictionary defines "swine" as a "pig" and "[a] contemptible or unpleasant person". It is apparent that by referring to David Cameron, then incumbent Prime Minister of the UK, the terrorists both describe their opponent as an animal and add substantial negative connotation to the wording of the message. It is also important to note that, according to Quran, pigs are considered to be unclean animals, forbidden for human consumption: "Forbidden to you (for food) are dead meat, blood, the flesh of swine" (Quran, Verse 173). Therefore, the terrorists not only dehumanize the opponent by comparing him to an animal, but degrade him even further through such a nomination.

(4c) "Oh, slave of the White House, oh, mule of the Jews". 
In this example, the terrorist speaker makes an obvious reference to Judaic tradition, in which "the Messiah's donkey / mule" is used to refer to a person who does the "dirty work" on behalf of someone else, which corresponds with the previously analyzed (4a) metaphor and establishes David Cameron (from the IS perspective) as well as the entire British government as a helpless entity that is controlled by the US.

(5) To Obama, the dog of Rome.

This animalistic metaphor marks another reference to "dogs". Notably, the majority of both Sunni and Shi'a Muslims consider dogs to be filthy animals, so it is only reasonable that the terrorists compare their main enemy (Barak Obama as the leader of the US at the time) to an animal with such negative connotation in Islamic discourse, which shows their detestation for their opponents. Secondly, one should also consider "the dog of Rome", which means servant of the Vatican, the center of the Catholic Church. It is widely known that Islam and Christianity have endured a long history of mutual mistrust and, in some cases, military aggression, most notably, the Crusades, which are also mentioned several times by the terrorist speakers and will be analyzed in greater detail later in the article.

It is noteworthy that zoomorphic metaphor is frequently used to describe enemies in modern political discourse. According to O. Solopova and A. Chudinov (2018), active use of zoomorphisms in representing the image of a society is connected with the biblical tradition of zoomorphic metaphorization of countries. The "Friend or Foe" opposition also gets expressed through animal symbols. Thus, the opponents are usually related to as rats, spiders or serpents while the allies are always associated with noble animals (lion) or birds (eagle, falcon, etc.) (Weiss 2008). Moreover, it is necessary to mention that dehumanization is one of the most successful tactics of suggestive influence. Hierarchical demotion of the enemy to the level of an animal in the terrorist's mind justifies any action towards the adversary, including inhumane executions, which have been posted online by the IS on numerous occasions.

The most eminent structural metaphor, found as a part of the current study, is the following: WAR-AS-RELIGIOUS-CONFRONTATION. Since the IS is a radical ideological group, appeal to religion plays a major role in the speaker's argumentation. Likening the group to a religious community enables the terrorists to justify their actions as being the will of Allah and present their enemies as opponents to religion and spirituality. Furthermore, persuading the target audience that the actions are legitimate becomes significantly easier, given certain commonality with the speaker. Faith can act as such commonality.

Linguistic expression of the mentioned conceptual metaphor is vast. However, it is possible to single out several most prominent units. For instance, enemy soldiers and the former US president Barak Obama are denoted by the speakers as Crusaders (Crusader army), and the military actions of the American troops on the IS-controlled territories are, accordingly, referred to as The Crusade:

(6) "Crusader, it is the support of Allah you did not gain anything, you returned to your base with loss and humiliation";

(7) “...it burns the Crusader army in Dabiq";

(8) “...the first American Crusader..." 
The Crusades, that took place in the medieval period, were a series of military actions aimed at gaining control over the Holy Land, which belonged to Muslims at the time. However, it is often claimed that the Crusades were sanctioned by the Catholic Church for nefarious political reasons, such as to establish dominance in the region. As a result, these campaigns led to further tensions between East and West, with the Crusaders often perceived as pillagers, rather than noble warriors and liberators. Thus, the IS speakers appeal to this historic fact and draw a parallel between the US army and the Crusaders, picturing the former as deceitful occupants that have invaded the IS-controlled territories under the pretext of liberation, actually pursuing political and economic goals (Fomin, Mona 2018).

It is worth mentioning that appeal to the Crusades is a prominent feature of Islamic discourse. For instance, Gamal Abdel Nasser (President of Egypt from 1954 to 1970 and President of the United Arab Republic from 1958 to 1970) makes the case for modern Western imperialism being similar to the Crusades (Asbridge 2012). However, while it is plausible that Muslim recipients of the message could interpret the metaphor in the intended way, one can only speculate whether it will produce the same effect on the Western audience, who are more likely to perceive Crusaders in a positive light.

The analyzed set of conceptual metaphors in the IS video messages allows us to conclude that, despite their varying linguistic expressions in terrorist discourse, all conceptual metaphors perform the same function - they contribute to realization of suggestive influence, which consists in embedding certain ideas into the public opinion and forming asocial, anti-political and pseudo-religious attitudes.

\section{Conclusion}

The analysis has revealed that the Islamic State speakers employ a set of preemptively devised conceptual metaphors that could be distributed to three categories: orientational, ontological and structural. The most prominent orientational metaphor in the analyzed video messages is WE-ON-TOP — ENEMY-UNDER-OUR-FEET, which is used by terrorists to exalt their organization above the opponents. The ENEMY ANIMAL model has been identified as the foundation for the largest number of ontological metaphors, which are used to both dehumanize the terrorists' enemies and evoke fear in the recipients. Furthermore, these metaphors also contain several references to religious writings and historical events, significant within the context of tensions between East and West. The most notable structural metaphor is WAR-AS-RELIGIOUSCONFRONTATION, which correlates with the terrorists' intention to present the military actions as a holy war, and their actions as sanctioned by the Quran, thus justifying inhumane actions towards their victims.

Overall, constant repetition of the abovementioned metaphors enables the IS terrorists to engrain specific images in the audience's minds, warranting successful suggestive influence. The data obtained could be perceived as a valuable contribution to the analysis of conceptual metaphors in terrorist discourse that we defined as one of the constituents of extremist discourse, which, in turn, belongs to political discourse.

(C) Andrey Fomin, Elizaveta Mona, 2019 (c) creative https://creativecommons.org/licenses/by/4.0/ 


\section{REFERENCES}

Asbridge, Thomas. (2012). The Crusades: The War for the Holy Land. Simon \& Schuster. 675-680.

Baigarina, Gerta P. (2004). Otsenochnost' kak universaliya publitsisticheskogo teksta. Tekst: Problemy i perspektivy. Aspekty izucheniya v tselyakh prepodavaniya russkogo yazyka kak natsional'nogo: materialy III Mezhdunar. nauchno-metodich. konferentsii., MGU, 17-19. (In Russ.)

Bubnova, Nataliya A. (2012). Analysis of mechanics of verbal manipulation with key words of social vocabulary exemplified in journalistic article. Russian Journal of Linguistics, 1, 86-97. (In Russ.)

Budaev, Eduard V. (2007). Stanovlenie kognitivnoi teorii metafory. Lingvokul'turologiya, Ekaterinburg, 1 (2007), 16-32. (In Russ.)

Chernyavskaya, Valeriya E. (2006). Diskurs vlasti i vlast' diskursa: problemy rechevogo vozdeistviya. Flinta: Nauka. (In Russ.)

Chudinov, Anatolii P. and Budaev, Eduard V. (2007). Stanovlenie i evolyutsiya kognitivnogo podkhoda k metafore. Novyi filologicheskii vestnik, 4 (1), 8-27. (In Russ.)

Danilova, Anna A. (2009). Manipulirovanie slovom v sredstvakh massovoi informatsii. Dobrosvet, Izdatel'stvo "KDU”. (In Russ.)

Ermoshin, Yurii A. (2011). On the significance and the linguistic means of emotional expressiveness in official public speech. Russian Journal of Linguistics, 4, 5-10. (In Russ.)

Fomin, Andrey G. and Mona, Elizaveta A. (2016). Sintaksicheskie osobennosti organizatsii zvuchashchei rechi terrorista. Rechevoe vozdeistvie v politicheskom diskurse: materialy Mezhdunar. nauch. konf. (Ekaterinburg, 1-3 dek. 2016 g.) (gl. red. A.P. Chudinov; FGBOU VO "Ural. gos. ped. un-t”). Ekaterinburg, 144-146. (In Russ.)

Fomin, Andrey G. and Mona, Elizaveta A. (2018). Leksicheskie osobennosti organizatsii rechi spikera-terrorista $\mathrm{v}$ video obrashcheniyakh IGIL (organizatsii, zapreshchennoi na territorii Rossiiskoi Federatsii). Politicheskaya lingvistika, 1 (67), 98-104. (In Russ.)

Gornostaeva, Anna A. (2018). Ironic metaphors in political discourse. Russian Journal of Linguistics, 22 (1), 108-125. doi: http://dx.doi.org/10.22363/2312-9182-2018-22-1-108-125.

Ivanova Svetlana V. (2016). Linguistic resources employed in an information warfare: demonization effect techniques. Political Linguistics Journal, 5 (59), 28-37. (In Russ.)

Ivanova, Yuliya E. (2013). Correlation of pitch variations on the emphasis of American public speaking. Russian Journal of Linguistics, 2 (2013), 37-44. (In Russ.)

Komalova, Liliya R. (2019). Representation of the Verbal Image of Aggression in the Informational Universe of the English-Language Mass Media. Russian Journal of Linguistics, 23 (1), 149-164. doi: http://dx.doi.org/10.22363/2312-9182-2019-23-1-149-164 (In Russ.)

Kondratieva, Olga N. (2002). The Vertical Axis 'Up-Down' in the Characteristics of the Concepts of Person's Inner World (on the material of Russian Chronicles). Sprache. Kultur. Mensch. Etnie. Landau: Verlag Empirische Padagogik, 90-96.

Kopnina, Galina A. (2008). Rechevoe manipulirovanie: uchebnoe posobie, 2-e izdanie. Moskva: Flinta.

Korosteleva, Larisa V. (2015). Ekstremistskii diskurs: priznaki, illokutsiya, pragmatika. Yurislingvistika, 4 (15). Nauchno-prakticheskii zhurnal, Kemerovo: Izdatelstvo KemGU, 18-23.

Kunitsyna, Valentina N., Nadezhda V. Kazarinova and Valentina M. Pogol'sha (2001). Mezhlichnostnoe obshchenie: uchebnik dlya vuzov. Sankt-Peterburg: Piter.

Kuprieva, Irina A. (2013). The peculiarities of verbalization of discretisation and syncretism of dynamic property of mentality. Russian Journal of Linguistics, 2, 45-50. 
Lakoff, George (2003). Metaphor and War, Again. UC Berkeley. Available on: https://escholarship.org/ uc/item/32b962zb.

Lakoff, George, Johnson, Mark (2008). Metaphors We Live By. University of Chicago Press.

Larina, Tatiana V., Vladimir I. Ozyumenko and Elena B. Ponomarenko (2011). Language mechanism used to manipulate publics opinion in English and Russian news texts. Russian Journal of Linguistics, 2, 28-37. (In Russ.)

Musolff, Andreas (2019). Creativity in Metaphor Interpretation. Russian Journal of Linguistics, 23 (1), 23-39. doi: 10.22363/2312-9182-2019-23-1-23-39.

Nickl, Michael M. (1998). Einige Entwürfe und Einträge in der neueren kommunikationswiaaenschaftlichen Pursuasionsforschung. Beiträge zur Persuasionsforschung. M. Hoffman, Hrsg. Ch. Keß-ler. Peter Lang Frankfurt.

OED Online, Oxford University Press, June 2019. Available on: www.oed.com.

Ozyumenlo, Vladimir (2017). Media discourse in an atmosphere of information Warfare: from manipulation to aggression. Russian Journal of Linguistics, 21 (1), 213-220 (In Russ.)

Ozyumenko, Vladimir and Larina, Tatiana (2017). From manipulation to aggression: analysis of media discourse in the situation of information confrontation. 4th International Multidisciplinary Scientific Conference on Social Sciences and Arts SGEM 2017, www.sgemsocial.org, SGEM2017 Conference Proceedings, 24-30 August, 2017, Book 3, Vol. 2, 737-744. doi: 10.5593/sgemsocial2017/32/S14.095.

Reddy, Michael J. (1979). The conduit metaphor: A case of frame conflict in our language about language. In Andrew Ortony (ed.), Metaphor and Thought. Cambridge, 284-310. doi: 10.1017/CBO9781139173865.012.

Savosin, Anton Y. (2013). Elements of artistic expression in English journalistic texts. Russian Journal of Linguistics, 1, 78-86.

Solopova, Olga and Chudinov, Anatoly (2018). Diachronic Analysis of Political Metaphors in the British Corpus: from Victory Bells to Russia's V-Day. Russian Journal of Linguistics, 22 (2), 313-337. doi: 10.22363/2312-9182-2018-22-2-313-337.

Skrebtsova, Tat'yana G. (2011). Kognitivnaya lingvistika: kurs lektsii. Filologicheskii fakul'tet SPbGU. (In Russ.)

Skrebtsova, Tat'yana G. (2018). Kognitivnaya lingvistika: klassicheskie teorii, novye podkhody. Moskva: Izdatel'skii Dom YaSK. (In Russ.)

Van Dijk, Teun A. (2006). Discourse and manipulation. Discourse \& Society, 17 (2), 359-383.

Vezhbitskaya, Anna (1996). Prototipy i invarianty. Yazyk. Kul'tura. Poznanie (otv. red. M.A. Krongauz). Moskva. (In Russ.)

Volkova, Yana A. and Panchenko, Nadezhda N. (2016). Destructiveness in political discourse. Russian Journal of Linguistics, 20 (4), 161-178. doi: http://dx.doi.org/10.22363/2312-91822016-20-4-160-178 (In Russ.)

Weiss, Daniel (2008). Animals in Soviet propaganda: verbal and graphic stereotypes. Political linguistics, 25.

Zaripov, Ruslan I. (2014). Manipulation impact through metaphors in political discourse. Russian Journal of Linguistics, 2 (2014), 145-158. (In Russ.)

\section{Article history:}

Received: 07 February 2019

Revised: 15 March 2019

Accepted: 01 May 2019 


\section{История статьи:}

Дата поступления в редакцию: 15 марта 2019

Дата принятия к печати: 01 мая 2019

\section{Bionote:}

ANDREY G. FOMIN is Ph.D. in Philology, Professor of the department of Translation Studies and Linguistics at the Institute of Philology, Foreign Languages and Media Communications, Kemerovo State University (Russia). His research interests include gender linguistics, linguapersonology and psycholinguistics.

Contact information: e-mail: andfomin67@mail.ru

ELIZAVETA A. MONA is a Post-graduate student at the Institute of Philology, Foreign Languages and Media Communications, Kemerovo State University (Russia). Her research interests include linguapersonology, psycholinguistics and political linguistics.

Contact information: e-mail: elizaveta-mona@yandex.ru

\section{Сведения об авторах:}

АНДРЕЙ ГЕННАДЬЕВИЧ ФОМИН - доктор филологических наук, профессор кафедры переводоведения и лингвистики Института филологии, иностранных языков и медиакоммуникаций Кемеровского государственного университета (Россия). Научные интересы:: гендерная лингвистика, лингвоперсонология, психолингвистика.

Контактная информация: e-mail: andfomin67@mail.ru

ЕЛИЗАВЕТА АЛЕКСАНДРОВНА МОНА - аспирант Института филологии, иностранных языков и медиакоммуникаций Кемеровского государственного университета (Россия). Научные uнтересы: лингвоперсонология, психолингвистика, политическая лингвистика.

Контактная информация: e-mail: elizaveta-mona@yandex.ru 